\title{
Dramatic Reduction of LATS2 Tumor Suppressor Protein Expression in Patients with CLL: Evaluation of LATS2 Levels with Clinical Features and Immunophenotypic Profile
}

\author{
Esra SERT ${ }^{1,2}$, Ender COSKUNPINAR ${ }^{1,3}$, Mustafa N. YENEREL ${ }^{2}$, Melih AKTAN², \\ Derya OZTURK ${ }^{3}$, Oguz OZTURK ${ }^{1}$, Hulya YILMAZ-AYDOGAN ${ }^{1}$ \\ ${ }^{1}$ Istanbul University, Aziz Sancar Institute of Experimental Medicine, Department of Molecular Medicine \\ ${ }^{2}$ Istanbul University, Istanbul Faculty of Medicine, Department of Hematology \\ ${ }^{3}$ Istanbul University, Istanbul Faculty of Medicine, Department of Medical Genetics, \\ Division of Internal Medicine, Istanbul, TURKEY
}

\begin{abstract}
Chronic lymphocytic leukemia (CLL) is characterized by the accumulation of the malign lymphocytes in the bone marrow and blood. LATS2 (Large Tumor Suppressor Homolog 2) is an important component of the Hippo pathway, which plays a crucial role in regulation of apoptosis, proliferation and cell growth. The present study was designed to determine the interactions between LATS2 (Large Tumor Suppressor Homolog-2) expression on risk of Chronic lymphocytic leukemia (CLL). In 28 patients with CLL and 20 controls, LATS2-mRNA and LATS2-protein expressions were measured by quantitative reverse-transcription-PCR and Western blotting techniques, respectively. The LATS2 expressions were down-regulated in the CLL group compared to the controls. We observed that the percentage of CD20 was higher in CLL subjects with the LATS2-mRNA Fold change (FC) of $\leq 0.1$ than those with the LATS- mRNA FC of $>0.1$ ( $p=0.057$ ), while interestingly, the percentage of CD3, CD8, and CD56 T-cell markers was lower in CLL subjects with the FC of $\leq 0.1$ than those with the LATS2-mRNA FC of $>0.1(p=0.004, p=0.008$ and $p=0.058$, respectively). The relationships among between the immunophenotypically determined B-cell marker-CD20, T cell markers-CD3, CD8 and CD56 and LATS2-mRNA levels may suggest possible diagnostic/ prognostic value of LATS2 in CLL. We suppose that these markers may be significant indicators of the severity or advanced stages of the CLL.
\end{abstract}

Keywords: CLL, LATS2, expression, Western Blotting, qRT-PCR

\section{ÖZET}

KLL Hastalarında LATS2 Tumör Baskılayıcı Protein Düzeylerinde Çarpıcı Azalma: LATS2 Düzeylerinin Klinik Özellikler ve İmmunfenotipik Profile Değerlendirilmesi

Kronik lenfositik lösemi (KLL) malin lenfositlerin kemik iliği ve kanda birikimi ile karakterizedir. LATS2 (Büyük Tumör Baskılayıcı Homolog 2), apoptoz, proliferasyon ve hücre büyümesinde elzem rol oynayan Hippo yolağının önemli bir komponentidir. Bu çalışma LATS2 mRNA ve protein ifadelenme (ekspresyon) seviyeleri ile KLL riski arasındaki etkileşimleri belirlemek ve KLL olgularının immunfenotipleri ile ilişkilerini değerlendirmek için düzenlenmiştir. Çalışmaya 28 KLL'li hasta ve 20 kontrol dahil edilmiştir. LATS2 gen ifadelenmesi ve protein analizi sırasıyla kantitatif ters- transkripsiyon PCR v eve Western Blotlama ile ölçülmüştür.T ve B hücrelerinin yüzey antijen ekspresyonları Flow Sitometri yöntemiyle belirlenmiștir. LATS2 mRNA ve protein ekspresyonları KLL grubunda kontrollere göre așağı düzenlenmiştir (down-regulated). LATS2 mRNA kat değişimi (Fold change, FC), $\leq 0.1$ olan KLL hastalarında FC> 0.1 olanlara göre CD yüzdesi daha yüksek iken ( $p=0.057$ ), CD3, CD8 ve CD56 T hücre belirteçleri dikkat çekici şekilde $F C \leq 0.1$ olan KLL hastalarında FC> 0.1 olanlara göre daha düşüktür (sırasıyla, $p=0.004, p=0.008$ ve $p=0.058$ ). Sonuçlarımız KLL hastalarında LATS2 mRNA ekspresyonunun așağı düzenlendiğine işaret etmektedir. Ayrıca immunfenotipik olarak CD20 B hücre belirteci, CD3,CD8 ve CD56 T hücre belirteçleri ile LATS2 mRNA düzeyleri rasındaki ilişkiler KLL'de LATS2'nin tanısal potansiyel değerini önermektedir. Bu belirteçlerin KLL şiddeti ve ilerlemiş evreleri için önemli indikatörler olabileceği kanaatindeyiz.

Anahtar Kelimeler: KLL, LATS2, ekspresyon, Western Blotlama, qRT-PCR 


\section{INTRODUCTION}

Chronic lymphocytic leukemia (CLL) is characterized by the enlargements of lymph nodes, liver and spleen, and the accumulation of malignant lymphocytes in bone marrow and blood. Being the most common type of leukemia in adults, the clinical course of CLL displays profound clinical heterogeneity. It is more prevalent among males (male to female ratio, 2:1), and the annual incidence of CLL is $2-3$ cases per $100,000 .^{1-3}$

CLL is a clinically heterogenous disease characterized by the accumulation of CD5+ and CD23+ B-cell lymphocytes. Genetic and molecular mechanisms that lead to the disease are not clear. Nonetheless, recent research suggests that the interaction of apoptosis and survival signaling modulation may be the key factor. ${ }^{4,5}$ The $\mathrm{Bcl}-2$ protein of the anti-apoptotic family (bcl-2, bcl-xl, bcl-w and mcl1) and the proapoptotic proteins (Bax, Bak) are important mediators of apoptosis. As a result, several apoptotic mechanisms including the balance between bcl-2 from the anti-apoptotic family and proapoptotic (bax) proteins are not only implicated in the pathogenesis of CLL but also in response to chemotherapy in CLL. 4,5

LATS2 is known as the second novel member of the Large Tumor Suppressor (LATS) gene family that is also known as KPM. LATS2 is involved in the negative regulation of the $\mathrm{G} 1 / \mathrm{S}$ or $\mathrm{G} 2 / \mathrm{M}$ transition in the cell cycle. This protein is localized in centrosomes during interphase, and early and late metaphase. ${ }^{6-8}$ Since it is localized in the centrosome, the LATS2 tumor suppressor protein functions as a mediator of cell cycle progression and apoptosis. ${ }^{7,9}$ LATS2 has been shown to induce apoptosis in lung cancer cells by playing role in the downregulation of antiapoptotic proteins such as Bcl-2 and Bcl-xL.7 Activation of Wnt/ $\beta$-catenin signaling has been implicated in many cancers such as colorectal cancer, prostate cancer and squamous cell carcinoma. ${ }^{10}$

LATS2 directly interacts with $\beta$-catenin in Wnt target gene transcription pathway. ${ }^{11,12}$ LATS2 tumor suppressor gene has been shown to be capable of inducing apoptosis and suppressing tumor development during cell proliferation. ${ }^{7}$ Although, due to these effects, many studies have investigated the role of LATS2 in the pathogenesis of various cancers and have demonstrated its association ${ }^{13-17}$, yet we did not encounter any study addressing its role in the pathogenesis of CLL. For this reason, the present study aimed to determine whether LATS2 was expressed in CLL at mRNA and protein levels, using quantitative real-time PCR and western blot analysis methods, and to investigate the clinical and prognostic value of the LATS2 expression in patients diagnosed with CLL.

\section{MATERIALS AND METHODS}

\section{Characteristics of the Study Population}

Between 2012 and 2016, peripheral blood samples were obtained from 28 patients including those who did or did not receive treatment, along with 20 healthy individuals, in the Hematology Outpatient Clinic, Internal Medicine Department, Istanbul Faculty of Medicine, Istanbul University. Questionnaires and medical records were used to confirm the diagnosis and cancer status. In patients diagnosed with CLL, mRNA expression of LATS2 tumor suppressor gene was analyzed by real-time PCR, and its protein levels were analyzed with the western blotting method. In addition, the statistical relationship was evaluated with immunophenotyping. Blood samples were obtained from patients who were being followed up in the Hematology Department, Istanbul Faculty of Medicine, Istanbul University. The experimental procedures of the study were conducted in the Molecular Medicine Department, Aziz Sancar Institute of Experimental Medicine, Istanbul University. Within the same day, flow cytometry analysis and RNA isolations were performed from the peripheral blood samples of the patients. For the western blotting analysis, the buffy coats were separated with ficoll and stored in eppendorf tubes at $-80^{\circ} \mathrm{C}$.

All procedures performed in studies involving human participants were in accordance with the ethical standards of the institutional and/or national research committee and with the Helsinki Declaration and its later amendments or comparable ethical standards. This study protocol was approved by the Local Ethical Committee at Istanbul University. Additional informed consent was obtained from all individual participants for whom identifying information is included in this article. 


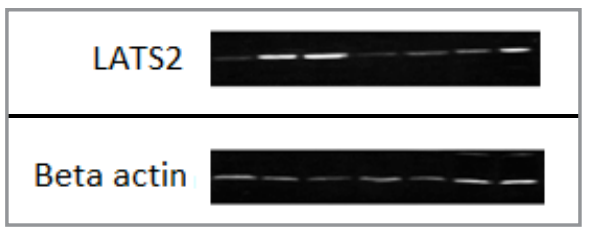

Figure 1. LATS2 and beta-actin protein levels demonstrated with the Western blotting analysis

\section{Western Blotting Analysis}

LATS2 protein levels was determined using the buffy coat fractions of the peripheral blood samples drawn from the CLL and control groups. Leukocytes were separated from the peripheral blood samples with ficoll. Proteins were extracted using protein extraction kit (ABCAM), concentrations were measured (Qubit) and proteins were run on an SDS polyacrylamide gel electrophoresis system. Then, proteins were transferred from the gel to the membrane. Primary antibodies for LATS2 and beta-actin, and secondary antibodies (ABCAM) were added. Enhanced chemiluminescence (ECL) method (ABCAM ECL kit) was used to the detection of proteins from Western blots. Figure 1 shows the LATS2 and beta-actin protein levels measured by the western blotting analysis.

\section{Flow Cytometry Analysis}

Leukocytes were isolated from the peripheral blood samples with the lysis method. Antibodies CD23, CD19, CD5, CD20, CD22 and CD56 were added. Antibody expression was analyzed in the FACS CANTO II device with the BD Facs Diva Software system

\section{Real-Time PCR Analysis}

In order to obtain total RNA from each patient and healthy controls, $500 \mu \mathrm{l}$ of peripheral blood drawn into EDTA-containing tube and the High Pure RNA Isolation Kit (Roche, ABD) was used. First strands of the cDNA samples were synthesized by using a commercial kit (Transcriptor High Fidelity cDNA Synthesis Kit, Roche, Germany). RNA samples were quantified using a NanoDrop ${ }^{\circledR}$ ND-1000 spectrophotometer (Thermo Fisher Sci-

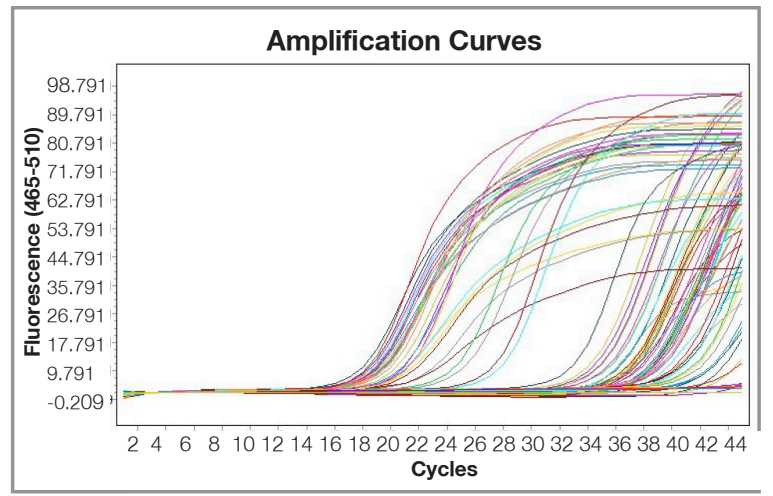

Figure 2. LATS2 and beta-actin gene expression curves

entific, Wilmington, Delaware, USA), and their integrity was checked electrophoretically. Gene expression analysis was performed by quantitative reverse transcription (qRT)-PCR (LightCycler 1.5, Roche, Germany). PCR reactions were conducted as follows: $95^{\circ} \mathrm{C}(10 \mathrm{~min})$ for polymerase activation and then 40 cycles at $95^{\circ} \mathrm{C}(15 \mathrm{sec}) / 60^{\circ} \mathrm{C}(1$ $\min )$. The Beta-Actin gene was used as the reference for normalization of the gene expression levels. The LATS2 gene expression levels analyzed $\Delta \Delta \mathrm{Ct}$ method (Figure 2). ${ }^{18}$

\section{Statistical Analysis}

All statistical analysis was performed using SPSS Statistical Program Version 20.0 (SPSS Inc. Chicago, USA). The significance of the differences in the LATS2 expression levels and clinic parameters were determined by the Mann-Whitney $\mathrm{U}$ test or McNemar (MN) test as needed. P values less than 0.05 were considered statistically significant.

\section{RESULTS}

\section{Clinical Findings of the Patients with Chronic Lymphocytic Leukemia.}

Table 1 shows demographical and biochemical characteristics of CLL patient and control groups. The CLL patient group had higher levels of fasting blood glucose $(p<0.05)$, creatinine $(p<0.01)$ and lactate dehydrogenase $(\mathrm{LDH})$ enzyme $(\mathrm{p}<0.05)$ levels compared to the control group.

The mean age of onset of CLL group was $59.75 \pm 1.85$ years, mean disease duration was $5.89 \pm 0.85$ years, 
International Journal of Hematology and Oncology

Table 1. Laboratory information and characteristic property of the study groups

\begin{tabular}{|c|c|c|c|}
\hline & \multicolumn{2}{|l|}{ Groups } & \multirow[b]{2}{*}{ p } \\
\hline & Control $(n=20)$ & CLL $(n=28)$ & \\
\hline Sex (Female/ male, n) & $10 / 10$ & $10 / 18$ & $>0.05$ \\
\hline Age (years, $\left.X_{ \pm} S E M\right)$ & $63.60 \pm 2.42$ & $65.64 \pm 2.06$ & $>0.05$ \\
\hline $\mathrm{BMI}\left(\mathrm{kg} / \mathrm{m}^{2}, \mathrm{X} \pm \mathrm{SEM}\right)$ & $27.16 \pm 0.84$ & $26.75 \pm 0.74$ & $>0.05$ \\
\hline Smoking (n,\%) & $10(50.0)$ & $8(28.6)$ & $>0.05$ \\
\hline Using alcohol (n,\%) & $4(20.0)$ & $4(3.6)$ & $>0.05$ \\
\hline WBC $\left(10^{3} / \mu \mathrm{L}, \mathrm{X}_{ \pm} \mathrm{SEM}\right)$ & $7.51 \pm 0.29$ & $108.18 \pm 18.54$ & $<0.001$ \\
\hline $\mathrm{HGB}(\mathrm{g} / \mathrm{dL}, \mathrm{X} \pm \mathrm{SEM})$ & $12.73 \pm 0.43$ & $11.57 \pm 0.34$ & $<0.05$ \\
\hline PLT $\left(10^{3} / \mu \mathrm{L}, \mathrm{X} \pm \mathrm{SEM}\right)$ & $264.05 \pm 15.12$ & $188.14 \pm 25.60$ & $<0.001$ \\
\hline $\operatorname{ALT}(\mathrm{U} / \mathrm{L}, \mathrm{X} \pm \mathrm{SEM})$ & $24.95 \pm 2.77$ & $22.38 \pm 4.22$ & $>0.05$ \\
\hline AST (U/L, X \pm SEM) & $19.26 \pm 0.84$ & $26.27 \pm 4.60$ & $>0.05$ \\
\hline Fasting Glucose (mg/dL, $\mathrm{X} \pm \mathrm{SEM}$ ) & $97.55 \pm 7.25$ & $115.96 \pm 6.71$ & $<0.05$ \\
\hline Creatinine (mg/dL, $\left.X_{ \pm} S E M\right)$ & $0.82 \pm 0.06$ & $1.07 \pm 0.12$ & $<0.01$ \\
\hline Urea (mg/dL, $X_{ \pm}$SEM) & $31.41 \pm 1.61$ & $35.42 \pm 3.68$ & $>0.05$ \\
\hline LDH (U/L, X \pm SEM) & $176.53 \pm 11.97$ & $282.89 \pm 25.99$ & $<0.05$ \\
\hline Beta2 $\left(\mu \mathrm{g} / \mathrm{mL}, X_{ \pm} \mathrm{SEM}\right)$ & - & $4.59 \pm 0.56$ & - \\
\hline
\end{tabular}

Statistical analysis was performed by nonparametric Mann-Whitney $U$ and Nc Memar statistical tests. CLL= Chronic Lymphocytic Leukemia, BMI= Body Mass Index, $\mathrm{WBC}=$ leukocyte, $\mathrm{HGB}=$ Hemoglobin, $\mathrm{PLT}=$ Platelet, $\mathrm{ALT}=$ Alanine aminotransferase, $\mathrm{AST}=$ aspartate aminotransferase, $\mathrm{LDH}=$ lactate dehydrogenase, $\mathrm{n}=$ sample number, $\mathrm{X} \pm \mathrm{SEM}=$ Mean \pm Standard error

\begin{tabular}{|c|c|c|c|c|c|}
\hline Patient number & $2^{\wedge}(-A v g \cdot(\operatorname{Delta}(C t))$ & $\begin{array}{l}\text { Fold Change } \\
\left(2^{\wedge}(- \text { Delta Delta Ct)) }\right.\end{array}$ & $95 \% \mathrm{Cl}$ & Fold regulation & $p$ value \\
\hline $\mathrm{H} 1$ & 0.000148 & 0.0531 & $(0.02,0.08)$ & -18.8305 & 0.004396 \\
\hline $\mathrm{H} 2$ & 0.000328 & 0.1678 & $(0.11,0.23)$ & -5.9587 & 0.008274 \\
\hline H3 & 0.010416 & 0.0008 & $(0.00001,0.00)$ & -1196.8279 & 0.140047 \\
\hline $\mathrm{H} 4$ & 0.00039 & 0.0154 & $(0.00001,0.04)$ & -65.0435 & 0.270345 \\
\hline H5 & 0.001473 & 0.0037 & $(0.00001,0.01)$ & -268.4172 & 0.317208 \\
\hline $\mathrm{H} 6$ & 0.000493 & 0.1344 & $(0.13,0.14)$ & -7.4384 & 0.000009 \\
\hline $\mathrm{H} 7$ & 0.000148 & 0.037 & $(0.03,0.05)$ & -27.0021 & 0.004043 \\
\hline $\mathrm{H} 8$ & 0.000191 & 0.0479 & $(0.00001,0.10)$ & -20.8938 & 0.00237 \\
\hline H9 & 0.000148 & 0.037 & $(0.03,0.05)$ & -27.0021 & 0.004043 \\
\hline $\mathrm{H} 10$ & 0.000148 & 0.1029 & $(0.07,0.14)$ & -9.7136 & 0.005231 \\
\hline $\mathrm{H} 11$ & 0.000148 & 0.1187 & $(0.07,0.17)$ & -8.4269 & 0.00565 \\
\hline $\mathrm{H} 12$ & 0.000148 & 0.0612 & $(0.02,0.10)$ & -16.3362 & 0.004587 \\
\hline $\mathrm{H} 13$ & 0.000165 & 0.0333 & $(0.03,0.04)$ & -30.03 & 0.000481 \\
\hline $\mathrm{H} 14$ & 0.000255 & 0.0216 & $(0.02,0.02)$ & -46.3661 & 0.000017 \\
\hline $\mathrm{H} 15$ & 0.000148 & 0.0725 & $(0.01,0.14)$ & -13.8007 & 0.005358 \\
\hline $\mathrm{H} 16$ & 0.000148 & 0.037 & $(0.03,0.05)$ & -27.0021 & 0.004043 \\
\hline $\mathrm{H} 17$ & 0.000202 & 0.0272 & $(0.00,0.05)$ & -36.7159 & 0.114247 \\
\hline $\mathrm{H} 18$ & 0.000148 & 0.037 & $(0.03,0.05)$ & -27.0021 & 0.004043 \\
\hline $\mathrm{H} 19$ & 0.000148 & 0.1358 & $(0.07,0.20)$ & -7.3615 & 0.006302 \\
\hline $\mathrm{H} 2 \mathrm{O}$ & 0.000148 & 0.0414 & $(0.02,0.06)$ & -24.1676 & 0.004125 \\
\hline $\mathrm{H} 21$ & 0.000148 & 0.0402 & $(0.03,0.05)$ & -24.9045 & 0.004099 \\
\hline $\mathrm{H} 22$ & 0.000148 & 0.0405 & $(0.03,0.05)$ & -24.6754 & 0.004096 \\
\hline $\mathrm{H} 23$ & 0.000148 & 0.066 & $(0.00001,0.14)$ & -15.1544 & 0.006076 \\
\hline $\mathrm{H} 24$ & 0.000148 & 0.9202 & $(0.48,1.36)$ & -1.0867 & 0.769218 \\
\hline $\mathrm{H} 25$ & 0.000148 & 0.3548 & $(0.24,0.47)$ & -2.8186 & 0.016051 \\
\hline $\mathrm{H} 26$ & 0.000148 & 0.037 & $(0.03,0.05)$ & -27.0021 & 0.004043 \\
\hline $\mathrm{H} 27$ & 0.000148 & 0.037 & $(0.03,0.05)$ & -27.0021 & 0.004043 \\
\hline $\mathrm{H} 28$ & 0.000148 & 0.1481 & $(0.08,0.22)$ & -6.7505 & 0.006564 \\
\hline
\end{tabular}




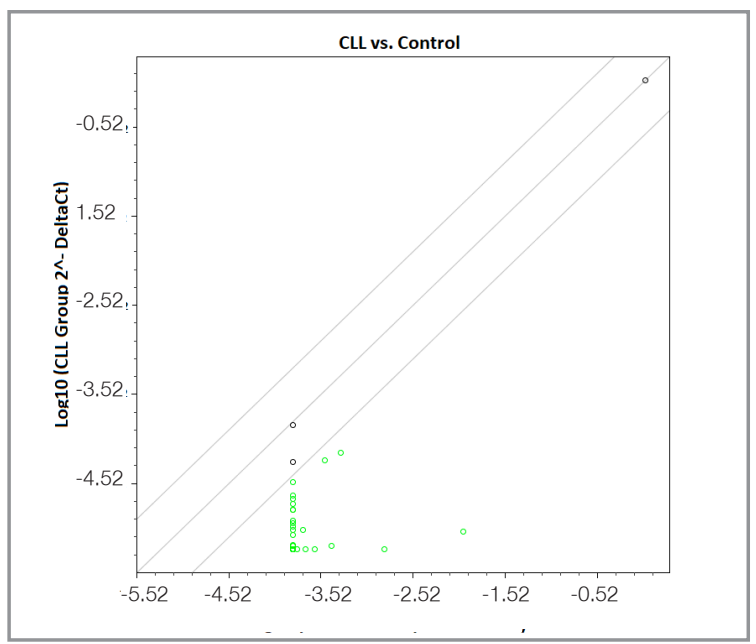

Figure 3. Scatter plot of the LATS2 gene expression levels

and $28.6 \%$ of the patients received treatment. The majority of the patients were between the stages 0 and II according to the RAI staging system in this study.

When patients with CLL were categorized as early stage (Stage 0 and Stage I) and advanced stage (Stage II, Stage III and Stage IV), it was determined that $46.4 \%$ of the patients had early stage disease and $53.6 \%$ of the patients had advanced stage disease.

\section{Analysis of the LATS2 Gene Expression}

Table 2 shows fold change of LATS2 gene expression in 28 patients with CLL in comparison to the control group, and also the associated $\mathrm{p}$ values. Twenty-five of the 28 patients included in the study showed lower LATS2 gene expression levels compared to the control group, which is statistically significant $(\mathrm{p}<0.05)$. The LATS 2 mRNA fold change values were found to vary between 0.0008 0.9202 , with a mean fold change value of $0.1011 \pm$ $0.033(\mathrm{X} \pm \mathrm{SEM})$.

The LATS2 gene expression levels of the patients diagnosed with CLL were displayed in Figure 3. The results indicated that the LATS2 expression is downregulated in CLL patient as compared to controls.
Comparison of the LATS2 Protein Expressions Across the Patients Diagnosed with CLL and Healthy Controls

Table 3 demonstrates the LATS2 protein levels in the CLL patient and control groups as measured by the Western blotting method. We find no significantly difference between LATS2 protein levels and study groups ( $\mathrm{p}>0.05$, Mann-Whitney $\mathrm{U}$ test).

In CLL patients, LATS2 protein level was found to be higher than in the control group. However, this relative increase is misleading. Average peripheral blood WBC counts are 108.18 \pm 18.54 in the CLL group and 7.51 \pm 0.29 in the control group. Therefore, when we examine it in proportion to peripheral blood leukocyte count, the higher LATS2 protein expression in CLL patients is misleading $(1.76 \pm 0.62$ in the CLL group vs. $0.96 \pm 0.49$ in the control group). The human peripheral blood leukocytes consist of lymphocytes, eosinophils, basophils, neutrophils and monocytes, and lymphocytes, which constitute the $20-30 \%$ of this group in healthy individuals. When we proportionate to the leukocyte LATS 2 amount in the healthy controls, the proportion of the LATS2 protein amount to total leukocyte count should be approximately 13.80 in the CLL patients. Therefore, in fact, there is an approximately 7.8 fold reduction in the LATS2 levels in the patient group.

Additionally, when we compared the LATS2 protein/WBC ratios between control and CLL patient groups with Mann-Whitney U statistical test, we found that this ratio to be significant lower in the CLL patient group than in the control group ( $\mathrm{p}<$ 0.001) (Table 3). This result indicated that the LATS2 protein levels are downregulated in the CLL patient group.

\section{Flow Cytometry Analysis in Patients with CLL}

Flow cytometry examination was conducted on the CLL patient samples included in this study, and surface expressions were investigated. Surface antigen expressions were analyzed with the FACS CANTO II device using the BD FACS DIVA SOFTWARE system. The readings were performed with the FACS CANTO II device, which has 2 laser systems with 6 colors. Data were ex- 
International Jounal of Hematology and Oncology

\begin{tabular}{|c|c|c|c|}
\hline CLL patients & LATS2 protein level & Control & LATS2 protein level \\
\hline $\mathrm{H} 1$ & 0.45 & $\mathrm{~K} 1$ & 0.09 \\
\hline $\mathrm{H} 2$ & 12.23 & K2 & 0.72 \\
\hline H3 & 6.75 & K3 & 1.04 \\
\hline $\mathrm{H} 4$ & 0.75 & K4 & 9.98 \\
\hline H5 & 12.55 & K5 & 0.40 \\
\hline H6 & 2.91 & K6 & 0.03 \\
\hline $\mathrm{H} 7$ & 1.54 & $\mathrm{~K} 7$ & 0.05 \\
\hline $\mathrm{H} 8$ & 0.17 & K8 & 0.53 \\
\hline H9 & .63 & K9 & 0.22 \\
\hline $\mathrm{H} 10$ & 1.38 & K10 & 0.15 \\
\hline $\mathrm{H} 11$ & 0.35 & K11 & 2.13 \\
\hline $\mathrm{H} 12$ & 0.09 & K12 & 0.22 \\
\hline $\mathrm{H} 13$ & 1.64 & K13 & 0.04 \\
\hline $\mathrm{H} 14$ & 1.53 & K14 & 0.05 \\
\hline $\mathrm{H} 15$ & 0.16 & K15 & 0.53 \\
\hline $\mathrm{H} 16$ & 0.12 & K16 & 1.00 \\
\hline $\mathrm{H} 17$ & 0.11 & K17 & 0.19 \\
\hline $\mathrm{H} 18$ & 0.24 & K18 & 1.16 \\
\hline $\mathrm{H} 19$ & 0.58 & K19 & 0.57 \\
\hline $\mathrm{H} 2 \mathrm{O}$ & 0.53 & K20 & 0.13 \\
\hline $\mathrm{H} 21$ & 0.00 & & \\
\hline $\mathrm{H} 22$ & 0.22 & & \\
\hline $\mathrm{H} 23$ & 0.04 & & \\
\hline $\mathrm{H} 24$ & 0.12 & & \\
\hline $\mathrm{H} 25$ & 0.27 & & \\
\hline H26 & 2.73 & & \\
\hline $\mathrm{H} 27$ & 0.65 & & \\
\hline $\mathrm{H} 28$ & 0.68 & & \\
\hline GROUPS & LATS2 protein $(\mathrm{X} \pm \mathrm{SEM})$ & $\mathrm{p}$ value & \\
\hline CLL Patients & $1.76 \pm 0.62$ & 0.242 & \\
\hline \multirow[t]{2}{*}{ Controls } & $0.96 \pm 0.49$ & & \\
\hline & LATS2 protein/ WBC $\left(X_{ \pm}\right.$SEM) & & \\
\hline CLL Patients & $0.035 \pm 0.01$ & $p<0.001$ & \\
\hline Control & $0.137 \pm 0.07$ & & \\
\hline
\end{tabular}

pressed as percentages, and the statistical analyses were conducted using these percentage values. Table 4 shows the distribution of the cell surface antigens used as molecular markers in diagnosis, in the CLL patient group.

\section{The Association of LATS2 Levels with Clinical Parameters in Patients with CLL}

To assess whether LATS2 expression levels had any effect on clinical and metabolic parameters, we compared the baseline characteristics among the LATS2 mRNA Fold Change of $>0.1$ and $<0.1$ subgroups in the CLL patients (Table 5). BMI levels and CD20 percentages were significantly higher in the CLL subjects with the LATS2 mRNA Fold Change of $\leq 0.1$ than those with the LATS 2 mRNA Fold Change of $>0.1(p=0.027$ and $p=0.057$, respectively). However, CD3, CD8 and CD56 percentages were significantly lower in CLL subjects with the LATS2 mRNA Fold Change of $\leq 0.1$ than those with the LATS2 mRNA Fold Change of $>0.1$ $(\mathrm{p}=0.004, \mathrm{p}=0.008$, and $\mathrm{p}=0.058$ respectively).

In addition, we observed that LATS2 protein levels were higher in the group that had LATS2 mRNA fold change as $>0.1$ compared to the group that had LATS2 mRNA fold change as $\leq 0.1(2.16 \pm 1.48$ vs. $0.72 \pm 0.19$ ) (Table 5). 


\begin{tabular}{|lc|}
\hline \multicolumn{2}{|l|}{ Table 4. Distribution of cell surface antigens in the CLL patient group } \\
\hline Cell surface antigens & Mean value \\
\hline CD3 & $11.89 \pm 1.64$ \\
CD8 & $5.92 \pm 0.94$ \\
CD4 & $6.74 \pm 1.00$ \\
CD23 & $70.74 \pm 4.18$ \\
CD5+CD19 & $77.31 \pm 3.70$ \\
FMC7 & $3.79 \pm 1.50$ \\
CD20 & $63.01 \pm 5.41$ \\
CD22 & $49.27 \pm 6.21$ \\
CD38 & $16.46 \pm 4.51$ \\
CD56 & $3.34 \pm 0.61$ \\
\hline Mean value of percentage Cell Surface Antigens $(\mathrm{X} \pm S E M)$ \\
\hline
\end{tabular}

\section{DISCUSSION}

Chronic lymphocytic leukemia was initially described as a disease resulting from the gradual accumulation of cells due to impaired apoptosis mechanism. ${ }^{7,19,20}$ Several studies have shown that CLL cells arose from decreased expression of proapoptotic proteins such as Bax, and overexpression of several anti-apoptotic proteins such as Bcl2, Mcl-1, Bak and X-linked inactivator of apoptosis protein (XIAP). ${ }^{19,20}$ While wild-type VH gene causes rapid and unfavorable progression in CLL, mutant $\mathrm{VH}$ gene has been associated with longer

\begin{tabular}{|c|c|c|c|c|}
\hline \multicolumn{2}{|l|}{ Parameter } & \multirow{2}{*}{$\begin{array}{l}\text { LATS2 mRNA } \\
\text { Fold Change }>0.1 \quad(n=8) \\
3(37.5)\end{array}$} & \multirow{2}{*}{$\begin{array}{l}\text { LATS2 mRNA Fold } \\
\text { Change } \leq \mathbf{0 . 1}(\mathbf{n}=\mathbf{1 7}) \\
7(41.2)\end{array}$} & \multirow{3}{*}{$\begin{array}{l}\text { p values } \\
p>0.05\end{array}$} \\
\hline $\operatorname{Sex}(n, \%)$ & Female & & & \\
\hline & Male & $5(62.5)$ & $10(58.8)$ & \\
\hline \multirow[t]{2}{*}{ Treatment $(\mathrm{n}, \%)$} & + & $2(25.0)$ & $4(23.5)$ & $p>0.05$ \\
\hline & - & $6(75.0)$ & $13(76.5)$ & \\
\hline \multirow[t]{2}{*}{ CLL stage $(n, \%)$} & Early Stage & $2(25.0)$ & $8(47.1)$ & $p>0.05$ \\
\hline & Late Stage & $6(75.0)$ & $9(52.9)$ & \\
\hline \multirow[t]{2}{*}{ Age of onset of CLL $(n, \%)$} & $>60$ & $4(50.0)$ & $9(52.9)$ & $p>0.05$ \\
\hline & $\leq 60$ & $4(50.0)$ & $8(47.1)$ & \\
\hline \multirow[t]{2}{*}{ LATS2 Protein $(n, \%)$} & $>1.5$ & $6(75.0)$ & $13(76.5)$ & $p>0.05$ \\
\hline & $\leq 1.5$ & & $4(23.5)$ & \\
\hline CLL age of onset (year, $\mathrm{X} \pm \mathrm{SEM}$ ) & & $63.00 \pm 3.71$ & $59.29 \pm 9.85$ & 0.669 \\
\hline Lifetime diagnosedCLL (year, $X_{ \pm}$SEM) & & $8.63 \pm 2.04$ & $4.24 \pm 0.60$ & 0.066 \\
\hline $\mathrm{BMI}\left(\mathrm{kg} / \mathrm{m}^{2}, \mathrm{X} \pm \mathrm{SEM}\right)$ & & $24.29 \pm 1.14$ & $28.04 \pm 0.89$ & 0.027 \\
\hline WBC $\left(10^{3} / \mu \mathrm{L}, \mathrm{X} \pm \mathrm{SEM}\right)$ & & $86.13 \pm 19.06$ & $97.24 \pm 21.68$ & 0.887 \\
\hline HGB (g/dL, $X \pm S E M)$ & & $11.59 \pm 0.61$ & $11.46 \pm 0.43$ & 0.932 \\
\hline $\operatorname{PLT}\left(10^{3} / \mu \mathrm{L}, \mathrm{X}_{ \pm} \mathrm{SEM}\right)$ & & $241.0 \pm 74.80$ & $173.12 \pm 22.55$ & 0.215 \\
\hline $\operatorname{ALT}(\mathrm{U} / \mathrm{L}, \mathrm{X} \pm \mathrm{SEM})$ & & $35.77 \pm 12.65$ & $18.12 \pm 2.30$ & 0.190 \\
\hline AST $(\mathrm{U} / \mathrm{L}, \mathrm{X} \pm \mathrm{SEM})$ & & $39.75 \pm 13.99$ & $19.67 \pm 1.73$ & 0.056 \\
\hline Glucose (mg/dL, X \pm SEM) & & $120.38 \pm 10.56$ & $112.00 \pm 7.55$ & 0.406 \\
\hline Creatinine (mg/dL, $X_{ \pm}$SEM) & & $1.20 \pm 0.40$ & $1.01 \pm 0.06$ & 0.291 \\
\hline Urea (mg/dL, $X \pm S E M)$ & & $29.27 \pm 2.53$ & $39.14 \pm 5.74$ & 0.820 \\
\hline LDH (U/L, X X SEM) & & $273.75 \pm 45.16$ & $304.29 \pm 36.13$ & 0.711 \\
\hline Beta2 $\left(\mu \mathrm{g} / \mathrm{mL}, X_{ \pm} \mathrm{SEM}\right)$ & & $3.23 \pm 0.84$ & $5.49 \pm 0.61$ & 0.106 \\
\hline CD3 $(\%, X \pm S E M)$ & & $16.03 \pm 1.52$ & $8.64 \pm 1.90$ & 0.004 \\
\hline CD4 $\left(\%, X_{ \pm}\right.$SEM $)$ & & $8.03 \pm 1.41$ & $5.57 \pm 1.26$ & 0.086 \\
\hline CD5+CD19 $\left(\%, X_{ \pm}\right.$SEM $)$ & & $70.21 \pm 6.84$ & $81.89 \pm 4.79$ & 0.101 \\
\hline CD8 $(\%, X \pm S E M)$ & & $8.24 \pm 1.47$ & $3.64 \pm 0.65$ & 0.008 \\
\hline CD2O $(\%, X \pm S E M)$ & & $49.79 \pm 11.51$ & $72.92 \pm 5.44$ & 0.057 \\
\hline CD22 $(\%, X \pm S E M)$ & & $41.99 \pm 10.69$ & $54.96 \pm 8.46$ & 0.262 \\
\hline CD23 $(\%, X \pm S E M)$ & & $67.43 \pm 7.30$ & $73.52 \pm 5.35$ & 0.238 \\
\hline CD38 $(\%, X \pm S E M)$ & & $12.73 \pm 3.11$ & $16.44 \pm 6.93$ & 0.417 \\
\hline CD56 (\%, X \pm SEM) & & $5.28 \pm 1.69$ & $2.34 \pm 0.48$ & 0.058 \\
\hline FMC7 $\left(\%, X_{ \pm}\right.$SEM) & & $2.11 \pm 0.99$ & $4.84 \pm 2.41$ & 0.977 \\
\hline LATS2 Protein $(\%, X \pm S E M)$ & & $2.16 \pm 1.48$ & $0.71 \pm 0.19$ & 0.511 \\
\hline
\end{tabular}


survival and slow progression of the disease. ${ }^{21,22}$ Ligation of the CD38 present on mature B cells inhibits apoptosis and the upregulation of $\mathrm{Bcl}-2$ protooncogene. ${ }^{23}$

As a tumor suppressor, LATS2 have critical roles in centrosome duplication, mitotic activity, and genomic stability. By downregulating the E/CDK2 kinase activity, it provides negative regulation for G1/S transition phase., ${ }^{7,8}$ The LATS2 pathway is functionally implicated in cell proliferation, apoptosis, and cell migration. Studies have reported that it is a tumor suppressor gene that provides a positive regulation of apoptosis and a negative regulation of tumor development during cell proliferation. ${ }^{7}$ Recent studies have shown that LATS2 induces apoptosis in lung cancer cells by downregulating anti-apoptotic proteins such as Bcl-2 and Bcl-xL. Furthermore, it was shown that exogenous Bcl-2 or Bcl-xL blocked LATS2-induced apoptosis. $^{7,8}$

LATS2 provides negative regulation for $\mathrm{G} 1 / \mathrm{S}$ or $\mathrm{G} 2 / \mathrm{M}$ transition in the cell cycle. This protein is localized to centrosomes during interphase, and early and late metaphase. ${ }^{6-8}$ LATS2 has a regulatory role in cell cycle progression and apoptosis. ${ }^{6,9}$ Studies indicate that LATS2 is a tumor suppressor gene capable of inducing apoptosis and inhibiting tumor development during cell proliferation.7 LATS2 has also been associated with the activation of p53 and Mdm, which inhibits p53 ubiquitination. ${ }^{24}$ To the best of our knowledge, there has been no previous report in the literature concerning the potential association between expression levels of LATS2 and the clinical course of CLL. Therefore, in the present study, we aimed to investigate the diagnostic and prognostic value of the tumor suppressor LATS2 protein and its gene expression levels along with the immunophenotype profile in patients diagnosed with CLL. In focus of this, LATS2 mRNA and protein levels were analyzed in the CLL patient and control groups, together with immunophenotyping in patients.

In the present study, we observed that LATS2 gene expression was downregulated in the blood specimens of CLL subjects (mean LATS2 mRNA fold change value of $0.1011 \pm 0.033)$. Interestingly, it was found that the LATS2 protein levels was significantly increased in CLL cases. However, we predicted that this result was relativistic. The reason is, while average peripheral blood WBC count was $108.18 \pm 18.54$ among the CLL patients, it was $7.51 \pm 0.29$ in the control group. When we examined Lats2 protein level in proportioning to the peripheral blood leukocyte count, the elevated LATS2 protein expression observed among CLL patients was appear to be a misleading $(1.76 \pm 0.62$ in CLL patient group vs. $0.96 \pm 0.49$ in control group). The human peripheral blood leukocytes consist of lymphocytes, eosinophils, basophils, neutrophils and monocytes, and lymphocytes, which constitute 20$30 \%$ of this group in healthy individuals. If, it is proportioned the LATS2 protein level to the leukocyte in control group, the LATS2 protein amount in CLL patients should be approximately 13.80. Therefore, in fact, there is an approximately 7.8 fold reduction in the LATS2 levels in the patient group. It can be also conclude from this result that LATS2 protein levels correlated with LATS2 mRNA levels. Consequently, both LATS2 mRNA and LATS2 protein expressions were found be downregulated in the CLL patient group in comparison to the control group in the present study. This result suggests that the LATS2 is included in the pathogenesis and has diagnostic value in chronic lymphocytic leukemia, which is characterized by the accumulation of malignant lymphocytes in blood and bone marrow.

The CD23 and CD5+CD19 B cell markers are important for the confirmation of the CLL diagnosis. When the LATS2 gene expression was examined with the immunophenotyping results, we didn't observed any significant correlation to the LATS2 expression with these markers. Interestingly, in the CLL patient group, LATS2 mRNA expression fold change $2 \Delta \Delta \mathrm{Ct} \leq 0.1$ was significantly correlated with CD20 B- lymphocyte marker percentage fold change $>0.1(72.92 \pm 5.44$ and $49.79 \pm 11.51, p=$ 0.057). This association suggests that the LATS2 may be of a potential prognostic value for CLL. More interestingly, we observed that the percentages of CD3, CD4 and CD8 cell populations were lower in the CLL patients with LATS2 FC value $<0.1$ than in the patients with $\mathrm{FC}$ value $>0.1$ ( $\mathrm{p}=$ $0.004,0.086,0.008$, respectively). This result suggests that the $\mathrm{T}$ cell population in patients with low 
LATS2 expression is down by half. Our findings indicated that $\mathrm{T}$ cell function in CLL also contributes to the disease, suggesting that $\mathrm{T}$ cell immunity also decreases in patients with low tumor suppressor LATS2 expression. It was concluded that the demonstrated correlations might be instructive regarding the CLL progression, pathogenesis, and clinical heterogeneity.

Conclusion. The present study is the first one in the literature investigating association between tumor suppressor tumor suppressor LATS2 expression and the CLL clinic. It was found that the LATS2 expression is dramatically reduced in CLL, both mRNA and protein levels in the present study. Moreover, the inverse relationship between the immunophenotypically determined B-cell marker CD20 and LATS2 mRNA levels may suggest a prognostic value of LATS2 in CLL, and that a larger scale research is necessary to confirm these results. We believe that all these findings may provide guidance for future related studies.

\section{Acknowledgements}

The present work was supported by a grant from the Scientific Research Projects Coordination Unit of Istanbul University (Project No: 28845).

\section{REFERENCES}

1. Zenz T, Mertens D, Kuppers R, et al. From pathogenesis to treatment of chronic lymphocytic leukaemia. Nat Rev Cancer 10: 37-50, 2010.

2. Caligaris-Cappio F, Hamblin TJ. B-cell chronic lymphocytic leukemia: a bird of a different feather. J Clin Oncol 17: 399408, 1999.

3. Norman AD, Hanson CA, Achenbach SJ, et al. Incidence of Chronic Lymphocytic Leukemia and High Count Monoclonal B-cell Lymphocytosis using the 2008 Guidelines. Cancer 120: 2000-2005, 2014.

4. Del Principe Ml, Dal Bo M, Bittolo T, et al. Clinical significance of bax/bcl-2 ratio in chronic lymphocytic leukemia. Haematologica 101: 77-85, 2016.

5. Kipps TJ, Stevenson FK, Wu CJ, et al. Chronic lymphocytic leukaemia. Nat Rev Dis Primers 3: 16096, 2017.

6. Li Y, Pei J, Xia H, et al. Lats2, a putative tumor suppressor, inhibits G1/S transition. Oncogene 22: 4398-4405, 2003.
7. $\mathrm{Ke} \mathrm{H}$, Pei J, Ni Z, et al. Putative tumor suppressor Lats2 induces apoptosis through downregulation of $\mathrm{BCl}-2$ and $\mathrm{Bcl}-$ x(L). Exp Cell Res 298: 329-338, 2004.

8. Mukai S, Yabuta N, Yoshida K, et al. Lats1 suppresses centrosome overduplication by modulating the stability of $\mathrm{Cd}$ c25B. Sci Rep 5: 16173, 2015.

9. Yabuta N, Mukai S, Okada N, et al. The tumor suppressor Lats2 is pivotal in Aurora A and Aurora B signaling during mitosis. Cell Cycle 10: 2724-2736, 2011.

10. De Sousa E Melo F, Vermeulen L. Wnt Signaling in Cancer Stem Cell Biology. Cancers (Basel) 8: 60, 2016.

11. Li J, Chen X, Ding X, et al. LATS2 suppresses oncogenic Wnt signaling by disrupting $\beta$-catenin/BCL9 interaction. Cell Rep 5: 1650-63, 2013.

12. An Y, Kang Q, Yaofeng Zhao Y, et al. Lats2 Modulates Adipocyte Proliferation and Differentiation via Hippo Signaling. PLoS One 8: e72042, 2013.

13. Zhang Y, Hu CF, Chen J, et al. LATS2 is De-methylated and Overexpressed in Nasopharyngeal Carcinoma and Predicts Poor Prognosis. BMC Cancer 10: 538, 2010.

14. Guo C, Wang X, Liang L. LATS2-mediated YAP1 phosphorylation is involved in HCC tumorigenesis. Int J Clin Exp Pathol 8: 1690-1697, 2015.

15. Zheng YB, Xiao K, Xiao GC, et al. MicroRNA-103 promotes tumor growth and metastasis in colorectal cancer by directly targeting LATS2. Oncol Lett 12: 2194-2200, 2016.

16. Li W, Wang L, Katoh H, et al. Identification of a Tumor Suppressor Relay between the FOXP3 and the Hippo Pathways in Breast and Prostate Cancers. Cancer Res 71: 2162-2171, 2011.

17. Luo SY, Sit KY, Sihoe AD, et al. Aberrant large tumor suppressor 2 (LATS2) gene expression correlates with EGFR mutation and survival in lung adenocarcinomas. Lung Cancer 85: 282-292, 2014.

18. Livak KJ, Schmittgen TD. Analysis of relative gene expression data using real-time quantitative PCR and the 2(-Delta Delta C(T)) Method. Methods 25: 402-408, 2001.

19. Chiorazzi N, Rai KR, Ferrarini M. Chronic lymphocytic leukemia. N Engl J Med 352: 804-815, 2005.

20. Meyers JA, Su DW, Lerner A. Chronic Lymphocytic Leukemia and $B$ and T Cells Differ in Their Response to Cyclic Nucleotide Phosphodiesterase Inhibitors. The J Immunol 182: 54005411,2009

21. Byrd JC, Stilgenbauer S, Flinn IW. Chronic lymphocytic leukemia. Hematology Am Soc Hematol Educ Program 2004: 163-183, 2004.

22. Hamblin TJ, Davis Z, Gardiner A, et al. Unmutated Ig VH Genes Are Associated With a More Aggressive Form of Chronic Lymphocytic Leukemia. Blood 94: 1848-1854, 1999. 
International Journal of Hematology and Oncology

23. Sargent RL, Craig FE, Swerdlow SH. Comparison of Bcl-2, CD38 and ZAP-70 Expression in Chronic Lymphocytic Leukemia. Int J Clin Exp Pathol 2: 574-582, 2009.

24. Aylon $Y$, Michael D, Shmueli A, et al. A positive feedback loop between the p53 and Lats2 tumor suppressors prevents tetraploidization. Genes Dev 20: 2687-700, 2006.

\section{Correspondence:}

Dr. Hulya YILMAZ-AYDOGAN

Istanbul University

Aziz Sancar Institute of Experimental Medicine

Department of Molecular Medicine

Vakif Gureba Caddesi

Capa, 34093 ISTANBUL / TURKEY

Tel: (+90-212) 4142000 ,

Fax: (+90-212) 5324171

e-mail: yilmazh@istanbul.edu.tr 